\title{
Language Teaching Research Based on Applied Linguistics Theory
}

\author{
Huihui Xing \\ School of Foreign Languages, Shanxi Datong University, Datong, China \\ Email: huihui4070@sina.com
}

How to cite this paper: Xing, H.H. (2018) Language Teaching Research Based on Applied Linguistics Theory. Open Journal of Social Sciences, 6, 340-348. https://doi.org/10.4236/jss.2018.612029

Received: December 13, 2018 Accepted: December 20, 2018 Published: December 31, 2018

Copyright $\odot 2018$ by author and Scientific Research Publishing Inc. This work is licensed under the Creative Commons Attribution International License (CC BY 4.0).

http://creativecommons.org/licenses/by/4.0/

\section{c) (i) Open Access}

\begin{abstract}
In order to study language teaching under applied linguistic theory, two definitions of applied linguistics, the breakthrough in the definition of applied linguistics, and the return of the core content to education and teaching, are introduced. The research results of language teaching under the theory of applied linguistics in recent years are listed. Taking English language teaching as an example and combining with applied language teaching theory, relevant teaching experiments are designed. According to the experimental results, it is concluded that applied linguistic teaching theory can effectively improve students' interest in learning and enhance the effectiveness of language learning. Finally, it is concluded that applied linguistics theory should be based on language teaching, change the way of language teaching, and better transfer knowledge to students.
\end{abstract}

\section{Keywords}

Applied Linguistics Theory, Language Teaching

\section{Introduction}

Applied linguistics has two definitions: narrow sense and broad sense. In narrow sense, this discipline mainly studies intercultural communication terms and language teaching, mainly focusing on the internal research of linguistics. In broad sense, applied linguistics has been fully utilized in sociology, psychology, philosophy and logic, and has a certain guidance significance to the design of professional terms in various disciplines [1]. Therefore, whether it is a narrow paradigm to understand applied linguistics or a broad view of applied linguistics, scholars generally agrees that applied linguistics is a discipline to solve linguistic problems. Applied linguistics holds that people should reconstruct the language teaching system so as to link language with context and social practice [2]. In 
recent years, the application of applied linguistics in language teaching has been expanded, effectively enhancing the practicality of linguistics.

English vocabulary teaching is an extremely important part of English language teaching. In recent years, English vocabulary teaching has not received due attention. It is not insufficient input, but inappropriate vocabulary teaching methods. Teachers mechanically teach vocabulary. The traditional vocabulary teaching mode is: teachers read vocabulary lists - students read vocabulary by themselves - teachers explain usage - use new words to create sentences - students recite words mechanically after class [3]. According to the students' actual situation, this vocabulary teaching method is not very effective. There is no real use of words, and the role of students in vocabulary learning is neglected. Based on the above situation, the language teaching is mainly studied under applied linguistics theory.

\section{Literature Review}

From the beginning of the birth of applied linguistics, it has been defined as the continuous widening of the subject of language teaching and research to the field of applied linguistics research. While enriching the achievements of applied linguistics research, it also blurs the main research directions of applied linguistics to a certain extent, which leads to the difficulty of its definition. Therefore, the determination of the core content of applied linguistics has become a problem that must be solved. From the perspective of the definition of applied linguistics by scholars in the past fifteen years, language teaching has become the focus of attention of applied linguists again [4]. Some scholars believe that applied linguistics is committed to solving (at least improving) many social problems related to language, including how to better teach language, how to better diagnose pronunciation pathology, how to improve the training of interpreters and translators, how to design effective language test questions, how to evaluate the school's bilingual teaching plan, how to determine the language level of the population as a whole, and how to discuss language in discourse [5]. It is a broad definition of applied linguistics what new teaching methods and means can be proposed for education. But it is not difficult to find that language teaching plays a central role in it.

The content of applied linguistics teaching is extensive. Firstly, it discusses the application of peripheral disciplines in the broad linguistic category, involving the role of consciousness in second language acquisition, case studies in minority languages and linguistic phenomena in social communication. Secondly, it looks at the prospects and development of applied linguistic criticism on a global scale, such as linguistic criticism in the 21 st century, the problems and prospects of network language norms, and the prospects of relevant linguistic criticisms [6]. Finally, it discusses the contents of teaching, such as classroom teaching research, comparative approach in language acquisition, multilingual subject vocabulary and so on. In future research, applied linguistics teaching should be given a new definition, which is the practical narrow scope generated based on 
the errors of expression and comprehension in the process of communicative discourse. It develops new theories through existing theoretical achievements and adopts new models to solve the problems existing in communicative discourse.

\section{Methodology}

\subsection{An Analysis of the Present Situation of English Vocabulary Teaching in Senior High Schools}

Vocabulary learning is an important part of language learning. It is necessary to attach importance to vocabulary teaching. However, with the implementation of the new curriculum, English texts in senior high schools are becoming more difficult and the number of new words is increasing, which challenges the traditional vocabulary teaching. As the organizer of teaching, it is necessary to study the present situation of English vocabulary teaching in senior high schools and the contradiction between the requirement of new curriculum standards for vocabulary size of senior high school students and the existing vocabulary size of senior high school students. It also requires thinking about how to carry out effective vocabulary teaching under the new curriculum reform environment. In terms of vocabulary teaching under the theory of applied linguistics, through the specific application, understanding and consolidation of some vocabulary, students can not only better understand the true meaning of vocabulary, but also flexibly use vocabulary in different contexts [7] [8].

The researches on context theory and vocabulary teaching at home and abroad are reviewed, and according to the current situation of English teaching in senior high schools in China. Two research questions for language teaching under the theory of applied linguistics are put forward.

Firstly, can vocabulary teaching under the theory of applied linguistics improve students' vocabulary learning strategies?

Secondly, will vocabulary teaching based on applied linguistics improve students' vocabulary performance?

\subsection{Experimental Design of Application of Applied Linguistic Theory in Vocabulary Teaching of Senior High School}

In order to verify the above two questions, the subjects of this experiment are 120 students in two classes of the same grade in the same senior high school. The students of Grade 2017 are divided into two classes according to the results of the final exam of Grade One. The students of the two classes are quality classes in Grade Two. They are taught by the same teacher. Their English proficiency is the same, their learning content is the same, and their class schedule is the same. One class, as an experimental class, adopts a vocabulary teaching method that meets the students' memory rules, motivates students' enthusiasm in vocabulary learning and improves their vocabulary application ability to teach English vocabulary; the other class, as a control class, still adopts the traditional vocabulary teaching method, shown in the table below (Table 1). 
Table 1. Student information.

\begin{tabular}{ccc}
\hline Class & Number of students & English proficiency \\
\hline Experimental class & 60 & $\begin{array}{c}\text { Senior high school English } \\
\text { (the first semester of Grade Two) }\end{array}$ \\
Control class & 60 & $\begin{array}{c}\text { Senior high school English } \\
\text { (the first semester of Grade Two) }\end{array}$ \\
\hline
\end{tabular}

\subsection{Experimental Content}

The materials used in the experiment included nine Units (Unit3-Unitll) and two test papers in the second volume of full-time English textbook (compulsory) of the People's Education Press for Senior High Schools. The two tests before and after the experiment are mainly to understand the students' mastery of English vocabulary. Quantitative analysis and qualitative analysis are used in this experiment.

The experiment is conducted in three stages and completed in 16 weeks. The first stage is a week, from September 1 to 7, 2017, and the first stage is a questionnaire survey, the bottom-up test stage. Through the bottom-up test, it is known that before the experiment, the two classes have the same level of English proficiency. The second stage is the experimental stage. The experimental class adopts the vocabulary teaching method that conforms to the rules of students' memory, which can arouse students' enthusiasm in vocabulary learning and improve their ability to use vocabulary to teach English vocabulary. The control class adopts the traditional vocabulary teaching method. The experiment lasts for fourteen weeks. Finally, the vocabulary test after the experiment is carried out.

In the first stage, all the students in the control class and the experimental class participate in the questionnaire survey and the pre-experiment test. Questionnaires are conducted to find out students' views or suggestions on vocabulary teaching. The questionnaires are completed within 5 minutes before the test. Before the experiment, the content of the test is the four-acquired vocabulary required by the outline of the first volume of senior high school. The test time is 40 minutes.

From Table 2 and Table 3, it can be seen that the English scores of the two classes before the experiment are equal, there is no obvious difference, and they are at the same level. The second stage is the experimental stage. The content of the study is from Unit 3 to Unit 11 of Volume 2 (Part 1) of English, which is a Full-Time Textbook for Senior Middle Schools (compulsory).

\subsection{Teaching Method of Control Class}

Each class in the control class follows the traditional teaching method, with teachers as the center, and students learn vocabulary passively according to the traditional five-step method. The five steps are as follows: 
Table 2. Comparison of the average scores of the two classes before the experiment.

\begin{tabular}{ccc}
\hline Class & Number of students & Average \\
\hline Experimental class & 60 & 68.65 \\
Control class & 60 & 69.70 \\
\hline
\end{tabular}

Table 3. Comparisons of passing rates between the first two classes in the experiment.

\begin{tabular}{ccc}
\hline Class & Number of students & Passing rate \\
\hline Experimental class & 60 & 52.3 \\
Control class & 60 & 53.4 \\
\hline
\end{tabular}

Step 1: Read after teachers. The teacher reads the new words once, and then the students read twice following the teacher. This step focuses on the pronunciation, spelling and basic meaning of words. At this stage, most students cannot concentrate on learning the words they read.

Step 2: Read the words by themselves. After the first step is completed, the students begin to read new words by themselves. During this period, teachers walk around the classroom to supervise students' reading of words and correct students' pronunciation and other problems. But in this process, the students just read the word and do not think about the meaning of the word.

Step 3: Explain the usage of new words. In traditional teaching methods, this step is considered to be the most important step. After reading all the words, the teacher will explain the usage of the new words on the blackboard. Then, the teacher will further emphasize the meaning and spelling of the new words. In addition, the teacher will tell the students how to use new words and grammar. During the whole process, students will take notes according to the knowledge points written on the blackboard by the teacher.

Step 4: Make sentences with new words. After explaining the usage of the new words, the teacher will give an example of the words and tell them how to make sentences. Then, the students imitate the teacher to make sentences. The teacher picks out the mistakes and asks the students to correct them.

Step 5: Recite. Generally speaking, this is the last step of traditional teaching methods. Give the students two minutes to understand these words. At the same time, the teacher will teach the knowledge just learned. The teacher walks around the classroom to answer questions that the students don't understand.

\subsection{Teaching Methods in Experimental Class}

Step 1: Introduction to context-based approaches. It takes one or two weeks to complete this phase. Introduce six different background clues, including synonym clues, antonym clues, example clues, causal clues, context or general knowledge clues and summary clues. Use some typical examples to illustrate six clues. Teachers ask important questions to help students find clues and infer the meaning of new words. In the whole process, students not only learn new words, but also learn how to recognize new words. 
Step 2: Teacher's leadership. The second phase will take about five weeks. The teacher proposes vocabulary strategies to express the following words: Firstly, the teacher uses pictures, objects or simple strokes as cues to help students guess unfamiliar words. Secondly, teachers use context as a cue. Thirdly, teachers take the social and cultural background as a hint. Fourthly, teachers use linguistic context as a cue. Reading is the key to enlarging students' vocabulary and can improve their vocabulary learning ability. First, the students are asked to read the whole article and get unknown words, and then choose them one by one. In addition, the teacher guides the students to guess the meaning of unknown words according to six clues. Next, the teacher evaluates and explains these words in detail so that the students can understand them. After guessing the words correctly, the students should combine these words together to listen, speak, read and write.

Step 3: Student group work. It will take four weeks to complete this stage. At this stage, materials beyond their standard are selected from textbooks. Each group is given the same paragraph to guess the meaning of the new word. At the same time, the teacher moves around to ensure that the group discussion goes smoothly.

Step 4: Students personal learning. Students infer the meaning of new words by themselves.

The third stage mainly carries on the test after the experiment. The test time after the experiment is the same (40 minutes) as that in the first stage (test before the experiment), and the test type is the same as that in the first stage (test before the experiment). The content of the test is the vocabulary required by the syllabus of Unit 3 to Unit 11 of English Volume 2 (1) of the Full-time General Senior Middle School Textbook (compulsory).

From Table 2, it can be seen that the average scores of the experimental class and the control class before the experiment are similar (68.65 and 69.70), and the passing rate is very close. From this point of view, the English scores of the two classes before the experiment are similar, and there is no obvious difference, at the same level. However, from Table 4 and Table 5, it can be seen that the average scores of the experimental class and the control class are significantly different after the experiment. The average scores of the experimental class are significantly higher than those of the control class $(77.73>69.89)$. From Table 3 , from the passing rate of the two classes before the experiment, there is little difference between the two classes (52.3 and 53.4). By contrast, the passing rate of the experimental class is slightly lower than that of the control class, but after the experiment, the passing rate of the two classes is quite different.

Table 4. Comparison of the average scores of the two classes after the experiment.

\begin{tabular}{ccc}
\hline Class & Number of students & Average \\
\hline Experimental class & 60 & 77.73 \\
Control class & 60 & 69.89 \\
\hline
\end{tabular}


Table 5. Comparisons of passing rates between the two classes after the experiment.

\begin{tabular}{ccc}
\hline Class & Number of students & Passing rate \\
\hline Experimental class & 60 & 70.3 \\
Control class & 60 & 54.1 \\
\hline
\end{tabular}

\section{Results and Discussions}

Vocabulary teaching is an important part of English teaching in senior high schools, and it is also a long process. English teachers need to constantly guide and help students learn and memorize English vocabulary, so that students can learn to learn by themselves and ultimately improve the effectiveness of English vocabulary teaching and learning.

There is a significant difference in the test scores between the two classes after the experiment, but there is no significant difference in the test before the experiment. Thus, after sixteen weeks of using vocabulary teaching strategies for teaching, students in the experimental class have made greater progress than those in the control class. In the process of English teaching in senior high schools, English vocabulary teaching has always been a difficult problem. It has been proved effective and feasible to teach vocabulary by using relevant strategies that mainly teach vocabulary and word formation in context, so as to help students understand the meaning of new words and memorize vocabulary. Secondly, adopting relevant strategies in vocabulary teaching is conductive to guiding and helping students to try to learn English vocabulary by using relevant learning strategies, so as to enhance students' interest and effectiveness in English vocabulary learning.

English vocabulary teaching is very important for English teaching in senior high school. Effective English vocabulary teaching strategies can improve the effectiveness of English vocabulary teaching, enhance students' interest in learning English vocabulary, and ultimately enhance the effectiveness of English learning, which can be seen from the literature at home and abroad. In the classroom practice of English vocabulary teaching in senior high schools, teachers can help students understand and memorize English vocabulary by choosing and properly using vocabulary teaching strategies. On the one hand, they can improve the effectiveness of vocabulary teaching; on the other hand, they can help and guide students to choose, use and strengthen English learning strategies suitable for themselves, and finally make English vocabulary teaching benefits from each other with learning in senior high schools.

\section{Conclusions}

Applied linguistics is generated based on the fruitful achievements of language teaching and becomes an independent science. Its emergence cannot be separated from the actual needs of language teaching. The initial research field of applied linguistics is also language teaching. With the continuous development of 
society and science and technology, the renewal of linguistic theories and the advancement of interdisciplinary studies, the scope of applied linguistics research has been expanding, and its definition has been extended from simple language teaching to all aspects of daily life related to language use. However, language teaching is still the most important research focus and core of applied linguistics, and also the long-term development direction of linguistics. Although the sample size involved in this study is relatively small. The experiment chooses the key classes, but it does not completely exclude the factors of students' willingness to learn. Therefore, there are some limitations in the study.

Teachers should establish a comprehensive teaching system according to classroom teaching objectives, constantly learn advanced foreign teaching experience, and fully integrate it with domestic teaching characteristics. In the process of classroom teaching, not only teachers need comprehensive guidance to control the pace of teaching, but also students need to actively cooperate with teachers' classroom process and actively participate in classroom learning. In addition, teachers should communicate with students in time, understand the problems existing in students' practice, make a comprehensive analysis of students' practice, and rationally adjust teaching strategies according to the analysis results. In the teaching system, it is also necessary to set up corresponding practice instructors, conduct special counseling investigation on students' practical work, and collect teaching cases, teaching plans and other materials from students' practice.

To cultivate high-quality language talents, it needs to start with teaching contents, teaching methods and teacher team. High-quality talents need not only basic literary accomplishment, but also social practice ability. Therefore, teachers need to combine applied linguistics theory with practice in the classroom teaching process to cultivate social talents, which is also the purpose of language teaching in China. Of course, no matter what kind of development mode, it is necessary to do not ignore the basic principle of language itself. On the basis of changing the teaching mode, better transferring knowledge to students and enabling them to learn and use it are the ultimate goal of language teaching.

\section{Conflicts of Interest}

The author declares no conflicts of interest regarding the publication of this paper.

\section{References}

[1] Block, D. (2017) Political Economy in Applied Linguistics Research. Language Teaching, 50, 32-64. https://doi.org/10.1017/S0261444816000288

[2] Charalambous, P., Charalambous, C. and Rampton, B. (2015) De-Securitizing Turkish: Teaching the Language of a Former Enemy, and Intercultural Language Education. Applied Linguistics, 38, amv063.

[3] Heidi, B. (2015) Invited Colloquium-On Publishing in Applied Linguistics: A Forum on Innovation and Challenges in a Changing World. AAAL Conference 2014. 
Language Teaching, 48, 3.

[4] Jalilifar, A.E.A. (2017) Thematicity in Applied Linguistics Textbooks: A Comparative Study of Foreword, Introduction and Preface. Iranian Journal of Language Teaching Research, 5, 15-36.

[5] Alkhatib, H. (2016) Issue of Identity and Boundary between Applied Linguistics and English Language Teaching. Arab World English Journal, 7, 430-447.

[6] Ehlers-Zavala, F.P., Ellis, S. and McCartney, E., Eds. (2015) Applied Linguistics and Primary School Teaching. Language Policy, 14, 87-89.

https://doi.org/10.1007/s10993-013-9292-9

[7] Kubanyiova, M. and Feryok, A. (2015) Language Teacher Cognition in Applied Linguistics Research: Revisiting the Territory, Redrawing the Boundaries, Reclaiming the Relevance. Modern Language Journal, 99, 435-449.

https://doi.org/10.1111/modl.12239

[8] Pei, Z.W. (2015) Classroom Discourse in College English Teaching of China: A Pedagogic or Natural Mode? Journal of Multilingual and Multicultural Development, 36, 1-17. https://doi.org/10.1080/01434632.2015.1015540 